\title{
WEED CONTROL IN SWEETPOTATOES
}

\author{
S. L. LEWTHWAITE ${ }^{1}$ and C. M. TRIGGS ${ }^{2}$ \\ ${ }^{I}$ New Zealand Institute for Crop \& Food Research Limited, \\ Mt Albert Research Centre, Private Bag 92169, Auckland \\ ${ }^{2}$ Department of Statistics, University of Auckland, Private Bag 92019, Auckland
}

\begin{abstract}
The sweetpotato (Ipomoea batatas (L.) Lam) crop, once established, requires little field management apart from weed control. Currently, weeds are minimised by a combination of hand-weeding, inter-row cultivation and the application of paraquat (100 $\mathrm{g}$ ai/ha) over the crop. In this study, alternative herbicide treatments were examined in a field trial. Hand-weeding produced the highest marketable yield (26.7 t/ha), significantly more than all other treatments apart from acetochlor $(2.4 \mathrm{~kg} \mathrm{ai} / \mathrm{ha})$, which produced $21.8 \mathrm{t} / \mathrm{ha}(\mathrm{P}<0.001)$. Weed numbers were significantly reduced to $3.5 \%$ (acetochlor) and $16.2 \%$ (paraquat) of the unweeded plots $(\mathrm{P}<0.001)$. There was a strong negative relationship between early weed count and final total root yield $\left(\mathrm{R}^{2}=84.0 \%\right)$.
\end{abstract}

Keywords: Ipomoea batatas, crop, herbicide, yield.

\section{INTRODUCTION}

Following release of the sweetpotato (Ipomoea batatas (L.) Lam) cultivar Owairaka Red in 1954, commercial production of sweetpotato or kumara in New Zealand increased. Over 1000 ha are now planted each year (Lewthwaite 1997). Generally sweetpotato are transplanted into the field in November and harvested in April. The sweetpotato crop is grown on moulds or ridges which raise the soil temperature, improve drainage and aid harvest. The transplants are watered in with tractor-drawn water carts which wet the soil along the crest of the mould. Under these conditions the inter-plant strip develops relatively early weed growth. Sweetpotato plants produce little ground cover over the first month following transplanting and the exposed shoulders of the mould erode, with soil movement sometimes limiting weed growth on the sides of the mould. The hollow between the moulds may then develop weed growth as poorer drainage conserves early rain. Cultivation can be used to keep the base and lower portions of the mould weed-free, but the inter-plant strip is difficult to access. While inter-row cultivation can destroy weeds and aid soil aeration, it may also disturb the sweetpotato plant. When residual herbicides are applied they must form an unbroken film to control weeds, but cultivation or erosion of the soil, along with cracks opening during dry weather, may damage the film and allow weed growth. From mid to late season, sweetpotato plants produce dense ground cover that smothers further weed germination.

The recommended weed control method at the time of Owairaka Red's release was shallow inter-row cultivation (Gillard 1955). The crop generally needed three to four weedings a season, and was hand hoed on the moulds and between plants (Coleman 1972). Although large weeds competed with the crop, deep mechanical weeding could dramatically reduce yield by disturbing the sweetpotato plants. Early New Zealand experimental trials found that sweetpotato plants were fairly tolerant to herbicides, but while the crests and bases of the moulds remained weed-free, the sides did not because of the spray distribution, so shallow herbicide incorporation before moulding was suggested (Webster 1962). The contact herbicide, paraquat, was recommended for sweetpotato in 1972 (Coleman 1972). Paraquat was applied over the crop while the weeds were small, and although some crop damage always occurred, it was considered less damaging than hand-weeding. Paraquat remains the herbicide most commonly used for weed control in the New Zealand sweetpotato crop, supplemented by interNew Zealand Plant Protection 53:262-268 (2000) 
row cultivation and hand-weeding.

A number of herbicides available in New Zealand have label claims for grass control in sweetpotato. However, alachlor (Foot 1997), which was evaluated for the sweetpotato crop in the Bay of Plenty, Gisborne and Ruawai areas (Scherp 1971) is the only broadleaf herbicide. The Dargaville area produces about $86 \%$ of the national sweetpotato crop, but the region has little irrigation water, so is reliant on rainfall. Alachlor is used by some growers, but it requires rain activation (up to $13 \mathrm{~mm}$ within 10 days of application) before it can provide 6-8 weeks of residual weed control. This study evaluated the effectiveness of a range of herbicides for use on sweetpotato in the Dargaville region.

\section{MATERIALS AND METHODS}

The trial was planted in a commercial field in the Dargaville region. The site had previously been in grazed pasture. Fertiliser $(150 \mathrm{~kg} / \mathrm{ha}$ of $15 \%$ potassic superphosphate and $50 \mathrm{~kg} / \mathrm{ha}$ of urea) was broadcast in early November 1998. The trial was transplanted into the field on 18 November 1998 and watered in by a tractor-drawn cart. There were 12 treatments (Table 1), each with four replicates arranged in a modified alpha design (Williams and John 1989). The trial plots were four rows wide by $4 \mathrm{~m}$ long; only the two middle rows (20 plants) were harvested, the outer rows being buffers. Each row was $0.75 \mathrm{~m}$ wide and within-row plant spacing was $0.30 \mathrm{~m}$. The soil was sampled on 16 December 1998 with the following analysis: phosphorus $49 \mathrm{mg} / \mathrm{ml}$, potassium 1.16 me/100 g, calcium $14.7 \mathrm{me} / 100 \mathrm{~g}$, magnesium $8.02 \mathrm{me} / 100 \mathrm{~g}$, sodium $0.41 \mathrm{me} / 100 \mathrm{~g}$, cation exchange capacity $33.3 \mathrm{me} / 100 \mathrm{~g}$, available nitrogen $187 \mathrm{~kg} / \mathrm{ha}, \mathrm{pH} 5.6$, and a volume/weight ratio of 0.89 for dried ground soil.

The herbicides were applied using a hand-operated backpack sprayer. The spray boom extended over the entire plot width $(3 \mathrm{~m})$ and delivered 307 litres/ha (Hardi 4110-12 spray nozzles). Seven of the herbicide treatments (alachlor, clomazone (240 $\mathrm{g} / \mathrm{ha}$ ), clomazone (480 g/ha), clomazone plus alachlor, dimethenamid, pendimethalin and flazasulfuron) were sprayed over the sweetpotato plants after transplanting (19 November 1998), while acetochlor was soil incorporated by hand before transplanting. The three remaining herbicide treatments (paraquat, pyridate $(450 \mathrm{~g} / \mathrm{ha}$ ) and pyridate $(675 \mathrm{~g} / \mathrm{ha})$ ) were applied over the sweetpotato plants on 16 December, following transplant establishment and early weed growth.

TABLE 1: Weed control measures evaluated in a sweetpotato trial at Dargaville during the 1998/99 season.

\begin{tabular}{lll}
\hline Treatment & Rate $(\mathrm{kg} \mathrm{ai} / \mathrm{ha})$ & Trade name \\
\hline hand-weeded & - & - \\
acetochlor & 2.400 & Trophy \\
paraquat & 0.100 & Gramoxone \\
dimethenamid & 1.350 & Frontier \\
clomazone plus alachlor & $0.240+1.440$ & Magister plus Lasso \\
alachlor & 1.920 & Lasso \\
pendimethalin & 0.990 & Stomp \\
pyridate (1) & 0.675 & Lentagran \\
pyridate (2) & 0.450 & Lentagran \\
clomazone (1) & 0.480 & Magister \\
clomazone (2) & 0.240 & Magister \\
flazasulfuron & 0.015 & YR160 \\
\hline
\end{tabular}

\footnotetext{
${ }^{1}$ Experimental herbicide
}

On 7 January, sweetpotato plant survival and phytotoxic effects were recorded, then weed growth was estimated from two randomly placed quadrats in each plot. In each plot, one $0.16 \mathrm{~m}^{2}$ quadrat was centred on the crest of a mould while the other was centred on a hollow between moulds and the weeds within the quadrats were harvested 
at soil level. The weeds were identified, counted and oven dried at $80^{\circ} \mathrm{C}$. Following assessment of the weed population and composition, the hand-weeded plots were completely weeded on 7 January with a further weeding on 30 January 1999.

Any weeds that germinated under the herbicide treatments were left undisturbed until the completion of the trial. The trial was hand harvested and assessed for yield on 14 April 1999. At harvest, all roots were graded either as marketable or waste (less than $25 \mathrm{~mm}$ diameter and/or distorted or diseased). A sub-sample of three marketable roots was removed from each plot and oven dried (20 April) at $80^{\circ} \mathrm{C}$ to calculate dry matter content. The data were analysed using the GENSTAT ${ }^{\mathrm{TM}}$ statistical software package.

\section{RESULTS AND DISCUSSION}

A total rainfall of $33.2 \mathrm{~mm}$ was recorded at Dargaville (data supplied by the National Institute of Water and Atmospheric Research Ltd) over the 10-day period immediately following spray application (19 November 1998). This rain should have provided adequate moisture for herbicides requiring rain activation. The three herbicide treatments (paraquat, pyridate $(450 \mathrm{~g} / \mathrm{ha})$ and pyridate $(675 \mathrm{~g} / \mathrm{ha}))$ applied on 16 December, after transplant establishment and following early weed growth, all produced various degrees of leaf chlorosis or leaf burn in the sweetpotato plants without causing plant death. None of the other herbicide treatments or the hand-weeded treatment showed evidence of any damage to the sweetpotato plants. The herbicides acetochlor (Chen et al. 1993), clomazone (Porter 1990) and alachlor (Herman et al. 1983; Galze and Hall 1990) have all been evaluated internationally and have shown no significant phytotoxic effects on sweetpotato.

The hand-weeded treatment gave the highest total yield (Table 2), but did not differ significantly from the acetochlor treatment $(\mathrm{P}>0.05)$. The marketable yield of the hand-weeded treatment was also the highest in the trial, but was not significantly different from the acetochlor treatment $(\mathrm{P}>0.05)$. None of the harvested roots from any treatment showed abnormal cracking or shape distortion. The saleable percentage of the crop and the root dry matter content did not differ significantly between treatments $(\mathrm{P}>0.05)$.

TABLE 2: Yield characteristics of the sweetpotato cultivar Owairaka Red following single applications of herbicides at Dargaville in the 1998/99 season.

\begin{tabular}{lcccc}
\hline Treatment & $\begin{array}{c}\text { Total } \\
\text { yield } \\
(\mathrm{t} / \mathrm{ha})\end{array}$ & $\begin{array}{c}\text { Marketable } \\
\text { yield } \\
(\mathrm{t} / \mathrm{ha})\end{array}$ & $\begin{array}{c}\text { Saleable } \\
\text { percentage } \\
(\%)\end{array}$ & $\begin{array}{c}\text { Root } \\
\text { dry matter } \\
(\%)\end{array}$ \\
\hline hand-weeded & 27.5 & 26.7 & 97.2 & 29.8 \\
acetochlor & 23.5 & 21.8 & 92.1 & 30.6 \\
paraquat & 21.5 & 20.2 & 93.5 & 30.7 \\
dimethenamid & 20.2 & 19.2 & 94.1 & 30.5 \\
clomazone plus alachlor & 19.0 & 18.0 & 93.7 & 31.2 \\
alachlor & 18.7 & 17.5 & 93.7 & 30.6 \\
pendimethalin & 14.8 & 14.0 & 93.8 & 31.4 \\
pyridate (1) & 17.3 & 16.5 & 95.4 & 30.5 \\
pyridate (2) & 14.2 & 13.3 & 94.3 & 30.4 \\
clomazone (1) & 12.8 & 12.0 & 91.9 & 31.6 \\
clomazone (2) & 11.7 & 10.7 & 92.3 & 31.3 \\
flazasulfuron & 11.7 & 10.7 & 92.0 & 30.8 \\
LSD (P<0.05) & 5.6 & 6.0 & 3.9 & 1.9 \\
\hline
\end{tabular}

The weed population (7 January 1998) represented by the hand-weeded plots consisted of redroot (Amaranthus retroflexus) 76.4\%, fathen (Chenopodium album) $12.0 \%$, grass (various) $7.6 \%$, creeping mallow (Modiola caroliniana) $1.4 \%$, black nightshade (Solanum nigrum) $1.1 \%$, staggerweed (Stachys arvensis) $1.0 \%$, white 
clover (Trifolium repens) $0.2 \%$, dandelion (Taraxacum officinale) $0.1 \%$ and scotch thistle (Cirsium vulgare) $0.1 \%$.

The hand-weeded plots effectively contained no weeds after the first weeding on 7 January and only one further weeding session was required. Five treatments significantly reduced weed numbers relative to the unweeded plots (evaluated 7 January): acetochlor (3.5\%), paraquat (16.2\%), dimethenamid $(21.1 \%)$, clomazone plus alachlor $(23.7 \%)$ and alachlor $(26.2 \%)$ (Table 3). Four treatments significantly reduced weed dry weight relative to the unweeded plots (evaluated 7 January): acetochlor $(24.1 \%)$, paraquat $(26.8 \%)$, pyridate at $675 \mathrm{~g} / \mathrm{ha}(35.8 \%)$ and pyridate at $450 \mathrm{~g} / \mathrm{ha}(40.2 \%)$ (Table 3$)$. However, plots treated with pyridate showed reduced weed dry weight due to the general chlorosis of both weeds and crop plants which followed its application rather than a reduction in weed numbers.

TABLE 3: Weed characteristics following single applications of various herbicides in a sweetpotato crop at Dargaville in the 1998/99 season.

\begin{tabular}{lcccc}
\hline Treatment & $\begin{array}{c}\text { Weed count } \\
\left(\text { per } \mathrm{m}^{2}\right)\end{array}$ & $\begin{array}{c}\text { Log weed } \\
\text { count }\end{array}$ & $\begin{array}{c}\text { Weed dry } \\
\text { weight } \\
\left(\mathrm{g} / \mathrm{m}^{2}\right)\end{array}$ & $\begin{array}{c}\text { Mean weed } \\
\text { dry weight } \\
(\mathrm{g})\end{array}$ \\
\hline hand-weeded & & 6.5 & 122.2 & 0.20 \\
acetochlor & 712.5 & 3.1 & 29.4 & 0.98 \\
paraquat & 25.0 & 4.7 & 32.8 & 0.24 \\
dimethenamid & 115.6 & 5.0 & 71.6 & 0.35 \\
clomazone plus alachlor & 150.0 & 5.1 & 68.4 & 0.55 \\
alachlor & 168.8 & 5.2 & 80.0 & 0.30 \\
pendimethalin & 193.8 & 5.9 & 113.8 & 0.31 \\
pyridate (1) & 368.8 & 5.5 & 43.8 & 0.21 \\
pyridate (2) & 250.0 & 5.8 & 49.1 & 0.17 \\
clomazone (1) & 337.5 & 6.0 & 129.4 & 0.26 \\
clomazone (2) & 434.4 & 6.4 & 111.3 & 0.27 \\
flazasulfuron & 621.9 & 5.5 & 104.7 & 0.80 \\
LSD (P<0.05) & 246.9 & 0.98 & 54.4 & 0.60 \\
\hline
\end{tabular}

${ }^{1}$ Back-transformed means.

${ }^{2}$ Prior to the first complete weeding on 7 January the hand-weeded plots were used to estimate the weed population and composition at the site. These plots were then maintained weed-free.

Redroot, fathen and grass made up $97 \%$ of all the weed plants by number. Paraquat significantly reduced redroot numbers relative to the unweeded plots $(\mathrm{P}<0.001)$ but not fathen or grass. On a commercial scale, paraquat application is often repeated to control both sequential weed germination and robust weeds. Cultivation or handweeding is used to control escapes of specific weeds such as fathen. Acetochlor achieved significant control of the predominant weeds (redroot, fathen and grass) at the site $(\mathrm{P}<0.001)$. Dimethenamid and the clomazone plus alachlor treatments gave significant reductions in the incidence of grass weeds $(\mathrm{P}<0.001)$.

Limited international research on acetochlor in the sweetpotato crop has shown it to have potential (Chen et al. 1993). No acetochlor residue levels have been detected in harvested roots $(0.01 \mathrm{ppm}$ detectable limit) following a full commercial season of plant growth (S.L. Lewthwaite, unpubl. data). In the current trial, acetochlor effectively controlled weed germination for a prolonged period without affecting crop growth. Incorporating acetochlor appeared to make it more robust to erosion, as despite some soil movement, weed control was maintained over the entire plot. Acetochlor belongs to the same chemical group (acetanilide) as alachlor, which currently has a label claim for use on sweetpotatoes. While plots treated with acetochlor contained very few weeds (less than a one-quarter of those seen in paraquat plots), they produced a similar total weed dry weight to plots treated with paraquat. Early in the season these plots had 
a small number of weed escapes which were not hand pulled and grew to become large plants, as can be seen by the mean weed dry weight (Table 3 ).

The relationship between early weed count (7 January) and final total yield (14 April) was further examined to see if early weed numbers could be used to predict final yield loss due to competition. Weeds that germinated within the plots were allowed to grow undisturbed and competed with the crop until harvest. Some of the chemical treatments reduced weed numbers within individual plots without any obvious effect on sweetpotato growth and were included in the analysis. The handweeded plots (which may have had some mechanical disturbance) and the paraquat and the pyridate-treated plots (which suffered some visible chemical damage) were removed from the analysis. A plot of the logarithm of total yield versus the logarithm of weed count shows a strong multiplicative relationship between early weed count and final total yield $\left(\mathrm{R}^{2}=84.0 \%\right)$ (Fig. 1). As the weed number doubled, total yield decreased by $18 \%(\mathrm{SE} 1.0 \%)(\mathrm{P}<0.001)$.

There is growing international interest in integrated approaches to weed control

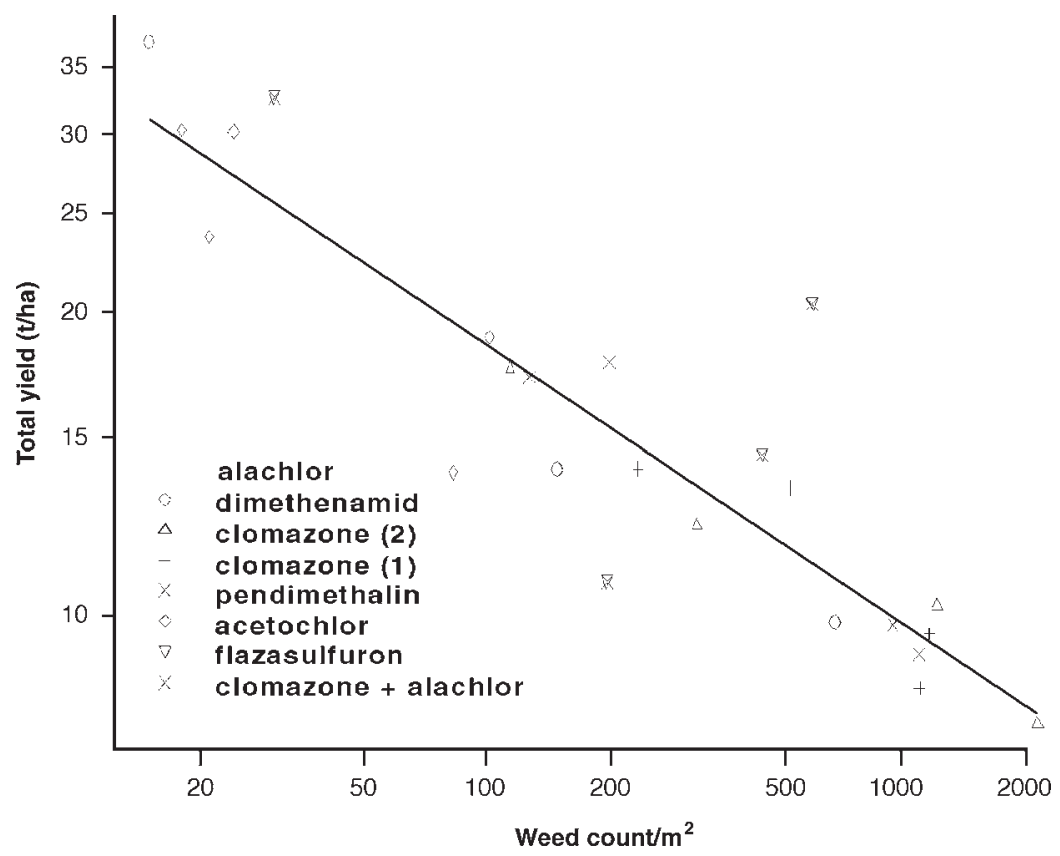

FIGURE 1: The relationship between early weed count and final total yield in a sweetpotato herbicide trial at Dargaville in the $1998 / 99$ season $\left(\mathbf{R}^{2}=\mathbf{8 4 . 0} \%\right)$.

in sweetpotato, incorporating herbicides, clonal tolerance (La Bonte et al. 1999), allelopathic effects (Harrison and Peterson 1991; Reinhardt et al. 1993; Peterson and Harrison 1995) and the critical period of crop-weed competition (Nedunzhiyan et al. 1998). An assessment of the early weed population in this trial allowed the final yield loss due to plant competition to be predicted. Further research in this area could produce management tools that would enable growers to assess the cost-benefit of weed control at low weed population levels. 
This trial examined weed control in a limited way, but further research into developing appropriate weed control strategies, incorporating repeat herbicide treatments, variations in application rates and different treatment combinations will assist in the future management of the sweetpotato crop. The herbicide acetochlor showed good control of the weed population represented at the site without affecting sweetpotato yield or quality. Acetochlor did not require rain to activate, provided a long period of residual weed control and soil incorporation appeared to solve the problem of weed germination associated with soil movement. Further research on acetochlor is required to confirm these results and to ascertain optimum application rates, incorporation methods and crop residue levels at harvest.

Paraquat is a contact herbicide commonly used in commercial practice. It caused damage to the sweetpotato plants, but effectively controlled some weed species while other species, such as fathen, were not controlled.

\section{ACKNOWLEDGEMENTS}

The following are gratefully acknowledged: New Zealand Kumara Distributors Ltd (NZKD) who commissioned this project; the New Zealand Vegetable and Potato Growers' Federation Inc. (Vegfed) and the Agricultural and Marketing Research and Development Trust (AGMARDT) for funding the project; Dr. M. Cannon (Louisiana State University) for suggestions on herbicide treatments and the agrichemical companies who supplied test material.

\section{REFERENCES}

Chen, H.K., Hu, H.Y., and Wang, X.F., 1993. Preliminary report on control of weeds with acetochlor in sweet potato fields. Plant Prot. 19: 6, 49.

Coleman, B.P., 1972. Kumara growing. New Zealand Department of Agriculture, Bulletin No. 294. 44 pp.

Foot, D., 1997. New Zealand agrichemical manual, Wham Chemsafe Limited, Wellington, New Zealand. 400 pp.

Galze, N.C. and Hall, M.R., 1990. Cultivation and herbicides for weed control in sweet potato (Ipomoea batatas). Weed Tech. 4: 518-523.

Gillard, S.O., 1955. Commercial kumara cultivation. New Zealand Department of Agriculture, Bulletin No. 294. 11 pp.

Harrison, H.F. Jr. and Peterson, J.K., 1991. Evidence that sweet potato (Ipomoea batatas) is allelopathic to yellow nutsedge (Cyperus esculentus). Weed Sci. 39: 308-312.

Herman, N.D., Monaco, T.J. and Sheets, T.J., 1983. Weed control with alachlor and residues in sweet potato (Ipomoea batatas) and soil. Weed Sci. 31: 567-571.

La Bonte, D.R., Harrison, H.F. and Motsenbocker, C.E., 1999. Sweetpotato clone tolerance to weed interference. HortSci. 34(2): 229-232.

Lewthwaite, S.L., 1997. Commercial sweetpotato production in New Zealand: Foundations for the future. Pp 33-50 In: Proceedings of the International Workshop on Sweetpotato Production System toward the 21st Century, Miyakonojo, Miyazaki, Japan, D.R. LaBonte, M. Yamashita and H. Mochida (Eds); Kyushu National Agricultural Experiment Station, Japan.

Nedunzhiyan, M., Varma, S.P. and Ray, R.C., 1998. Estimation of critical period of crop-weed competition in sweet potato (Ipomoea batatas L.). Advances in Hort. Sci. 12: 101-104.

Peterson, J.K. and Harrison, H.F. Jr., 1995. Sweet potato allelopathic substance inhibits growth of purple nutsedge (Cyperus rotundus). Weed Tech. 9: 277-280.

Porter, W.C., 1990. Clomazone for weed control in sweet potatoes (Ipomoea batatas). Weed Tech. 4: 648-651.

Reinhardt, C.F., Meissner, R. and Nel, P.C., 1993. Allelopathic effects of sweet potato (Ipomoea batatas) cultivars on certain weed and vegetable species. S. A. J. Plant and Soil 10: 41-44.

Scherp, L.A., 1971. Alachlor in vegetable crops. Proc. 24th N.Z. Weed and Pest 
Control Conf.: 132-134.

Webster, A.B., 1962. Weed control trials on vegetables in New Zealand - 1961-62. Proc. 15th N.Z. Weed Control Conf.: 128-132.

Williams, E.R. and John, J.A., 1989. Construction of row and column designs with contiguous replicates. Applied Statistics 38: 149-154. 